\title{
The Staining Effect of Iron (II) Sulfate on Nine Different Wooden Substrates
}

\author{
Ulrich Hundhausen ${ }^{1, *}$, Carsten Mai ${ }^{2}$, Maik Slabohm ${ }^{3}$, Florian Gschweidl ${ }^{4}$ \\ and Ronald Schwarzenbrunner 4 \\ 1 Department of R\&D and Consultancy, NTI (Norwegian Institute of Wood Technology), P.O. Box 113 \\ Blindern, 0314 Oslo, Norway \\ 2 Department of Wood Biology and Wood Products, University of Göttingen, 37073 Göttingen, Germany; \\ cmai@gwdg.de \\ 3 Faculty of Wood Technology and Construction, Rosenheim Technical University of Applied Sciences, \\ 83024 Rosenheim, Germany; maikslabohm@outlook.de \\ 4 Department of Wood Technology and Construction, Salzburg University of Applied Sciences, \\ 5412 Puch bei Hallein, Salzburg, Austria; fgschweidl.htb-b2015@fh-salzburg.ac.at (F.G.); \\ rschwarzenbrunner.htw-m2019@fh-salzburg.ac.at (R.S.) \\ * Correspondence: ulrich.hundhausen@treteknisk.no; Tel.: +47-976-57-599
}

Received: 7 May 2020; Accepted: 3 June 2020; Published: 9 June 2020

check for updates

\begin{abstract}
Leaving wooden façades uncoated has become popular in modern architecture, especially for large buildings like multi-story houses, in order to circumvent frequent maintenance, particularly repainting. To obtain a quick and even artificial graying of the entire façade that gradually turns into natural graying, a one-off treatment with iron (II) sulfate may be applied. Its mode of action is commonly ascribed to a reaction with phenolic wood extractives, especially hydrolyzable tannins. This does not however sufficiently explain iron (II) sulfate's ability to color wood species containing only marginal amounts of phenolic extractives; moreover, little is known about the influence of the wooden substrate and light conditions on the color development of façades treated with iron (II) sulfate. In the present study, we investigated the influence of wood extractives, exposure conditions, and nine different wooden substrates on iron (II) sulfate's staining effect. Spruce specimens with and without extractives were treated with a $4 \%$ iron (II) sulfate solution and exposed to sunlight behind window glass. Both wood types darkened slowly but significantly during 51 weeks of exposure. This shows that artificial graying with iron (II) sulfate (1) does not require precipitation unlike natural graying, (2) takes place without initial wood extractives, and (3) proceeds at a slow rate. Specimens protected from sunlight changed their color only slightly, suggesting that photo-induced phenoxyl and ketyl radicals from photolysis of lignin's ether bonds oxidize iron (II) to iron (III). Specimens made of spruce, pine, larch, and western red cedar (WRC) and exposed outdoors decreased strongly in lightness during the first two months of exposure. In contrast, a staining effect of iron (II) sulfate in terms of artificial graying was not seen on acetylated radiata pine, possibly because iron ions are hindered from entering the cell wall. Specimens partly protected by a roof overhang showed an uneven color development; this is due to the protection from radiation and not from precipitation as is known for natural graying.
\end{abstract}

Keywords: artificial graying; iron sulfate; sunlight; phenolic extractives; photodegradation; weathering; wooden façades

\section{Introduction}

The color stability of wood exposed outdoors is poor due to the influence of light, water, heat, microorganisms, oxygen, and atmospheric pollutants like sulfur dioxide. Of all these factors, 
solar radiation and water are crucial. Wood is highly susceptible to photodegradation, which is mainly ascribed to lignin's light absorption that results in the formation of aromatic free radicals. These free radicals from lignin react with oxygen forming alkoxyl and peroxyl free radicals, which in turn react with phenoxyl free radicals forming chromophoric compounds like quinones and aromatic ketones. The lignin macromolecule is fragmented in this process [1-4]. Lignin's highest absorption is in the UV wavelength range [5], but violet light was also found to be the component of the visible light region that contributes to photodegradation [6]. Photodegraded lignin is washed out by rain, leaving whitish holocellulose at the surface [7], which eventually becomes gray due to colonization by mold like the ubiquitous Aureobasidium pullulans [8].

Although some chemical treatments of wood contribute to its photostability, graying can only be effectively prevented by applying pigmented exterior coatings, which include UV absorbers, hindered amine light stabilizers (HALS), and inorganic photostabilizers [9-11]. A significant drawback of coatings is their need for frequent maintenance, which explains why leaving wooden façades uncoated has become popular in modern architecture, especially for large buildings like multi-story houses [12-14]. However, although photodegradation occurs rapidly after outdoor exposure [15], the natural graying process of a façade can take several years and varies greatly dependent on its cardinal direction and design details. Parts that are less exposed to wetting, for example under a roof overhang, will gray more slowly than those that are more exposed [12,16-18]. At the same time, studies have revealed that the homogeneity of the visual surface is positively correlated with the preference of consumers [19-21].

To obtain a quick and even graying of a façade, a gray "sacrificial" stain can be applied that gives an even color transition to natural graying during its degradation due to weathering [14]. There are several of such greying stains on the market. Alternatively, chemicals like bleaches or tannins with ferrous ammonium sulfate can be used [22]. In Scandinavia, a popular artificial graying method for wooden façades is a one-off treatment with iron (II) sulfate that gradually turns the color from artificial into natural graying [23-26]. Iron (II) sulfate, also called ferrous sulfate or green vitriol, has been used as colorant for centuries in many applications, as for instance to manufacture iron gall ink $[27,28]$, to blacken leather [29], and not least to stain wood [30,31]. Its mode of action is commonly ascribed to a reaction between iron and phenolics [32]. With gallic acid for instance, the iron (II) ion reacts to ferrous gallate, which subsequently oxidizes to a dark ferric pyrogallate complex [27]. This does not, however, sufficiently explain iron (II) sulfate's pronounced staining effect on wood species containing only marginal amounts of phenolic extractives such as Populus spp. or Picea spp. Moreover, little is known about the influence of the wooden substrate and light conditions on the color development of façades treated with iron (II) sulfate. Against this background, we investigated the influence of wood extractives, light, and nine different wooden substrates treated with iron (II) sulfate on the staining effect. Our hypothesis is that wood extractives can contribute but are not requisite in obtaining artificial graying with iron (II) sulfate.

\section{Materials and Methods}

\subsection{Experimental Design and Sample Preparation}

The study comprised 3 sample sets to investigate the influence of (i) wood extractives, (ii) light and (iii) wooden substrates (Table 1).

Sample set 1 included 4 veneer strips $\left(40 \times 30 \times 1 \mathrm{~mm}^{3} /(\mathrm{L} \times \mathrm{r} \times \mathrm{t})\right)$ with radial orientation of Norway spruce (Picea abies (L.) Karst.). The specimens were successively cut with a scroll saw from a wood block $\left(40 \times 30 \times 50 \mathrm{~mm}^{3} /(\mathrm{L} \times \mathrm{r} \times \mathrm{t})\right)$ with standing year rings. Two of 4 veneer strips were subjected to extraction in a Soxhlet apparatus for $6 \mathrm{~h}$ using a mixture of toluene:acetone:methanol (4:1:1) and dried at $20^{\circ} \mathrm{C} / 65 \% \mathrm{RH}$ for $48 \mathrm{~h}$. Subsequently, an aqueous solution of iron (II) sulfate ( $\left.4 \% w t / w t\right)$ was applied by brush on the front side of 1 extracted and 1 non-extracted veneer. The average application 
rate and standard deviation was $114(22) \mathrm{g} / \mathrm{m}^{2}$. Between application and exposure, the specimens were dried at $23{ }^{\circ} \mathrm{C} / 50 \% \mathrm{RH}$ for $48 \mathrm{~h}$.

Table 1. Experimental design. Numbers in brackets indicate non-exposed references.

\begin{tabular}{|c|c|c|c|c|c|}
\hline Sample Set & Substrate & Extracted $(y / n)$ & $\begin{array}{c}\text { Iron (II) } \\
\text { Treatment }(y / n)\end{array}$ & Exposure & $\begin{array}{l}\text { n/Exposure } \\
\text { Condition }\end{array}$ \\
\hline \multirow{4}{*}{1} & \multirow{4}{*}{ Norway spruce } & $y$ & $y$ & Indoor, sunlight & 1 \\
\hline & & $n$ & $y$ & Indoor, sunlight & 1 \\
\hline & & $y$ & $n$ & Indoor, sunlight & 1 \\
\hline & & $n$ & $n$ & Indoor, sunlight & 1 \\
\hline \multirow{2}{*}{2} & \multirow{2}{*}{ Norway spruce } & $n$ & $y$ & Indoor, sunlight & 3 \\
\hline & & $n$ & $y$ & Indoor, no light & 3 \\
\hline \multirow{18}{*}{3} & Norway spruce & $n$ & $y$ & $\begin{array}{c}\text { Outdoor, } \\
45^{\circ} / 90^{\circ} / 90^{\circ} \text { with roof }\end{array}$ & $3(1)$ \\
\hline & Norway spruce & $n$ & $n$ & $\begin{array}{l}\text { Outdoor, } \\
45^{\circ} / 90^{\circ} / 90^{\circ} \text { with roof }\end{array}$ & $3(1)$ \\
\hline & Siberian larch & $n$ & $y$ & $\begin{array}{l}\text { Outdoor, } \\
45^{\circ} / 90^{\circ} / 90^{\circ} \text { with roof }\end{array}$ & $3(1)$ \\
\hline & Siberian larch & $n$ & $n$ & $\begin{array}{l}\text { Outdoor, } \\
45^{\circ} / 90^{\circ} / 90^{\circ} \text { with roof }\end{array}$ & $3(1)$ \\
\hline & Oak & $n$ & $y$ & $\begin{array}{l}\text { Outdoor, } \\
45^{\circ} / 90^{\circ} / 90^{\circ} \text { with roof }\end{array}$ & $3(1)$ \\
\hline & Oak & $n$ & $n$ & $\begin{array}{l}\text { Outdoor, } \\
45^{\circ} / 90^{\circ} / 90^{\circ} \text { with roof }\end{array}$ & $3(1)$ \\
\hline & WRC & $n$ & $y$ & $\begin{array}{l}\text { Outdoor, } \\
45^{\circ} / 90^{\circ} / 90^{\circ} \text { with roof }\end{array}$ & $3(1)$ \\
\hline & WRC & $n$ & $n$ & $\begin{array}{l}\text { Outdoor, } \\
45^{\circ} / 90^{\circ} / 90^{\circ} \text { with roof }\end{array}$ & $3(1)$ \\
\hline & Scots pine heartwood & $n$ & $y$ & $\begin{array}{l}\text { Outdoor, } \\
45^{\circ} / 90^{\circ} / 90^{\circ} \text { with roof }\end{array}$ & $3(1)$ \\
\hline & Scots pine heartwood & $n$ & $n$ & $\begin{array}{l}\text { Outdoor, } \\
45^{\circ} / 90^{\circ} / 90^{\circ} \text { with roof }\end{array}$ & $3(1)$ \\
\hline & $\mathrm{Cu}$-HDO pine & $n$ & $y$ & $\begin{array}{l}\text { Outdoor, } \\
45^{\circ} / 90^{\circ} / 90^{\circ} \text { with roof }\end{array}$ & $3(1)$ \\
\hline & $\mathrm{Cu}-\mathrm{HDO}$ pine & $n$ & $n$ & $\begin{array}{l}\text { Outdoor, } \\
45^{\circ} / 90^{\circ} / 90^{\circ} \text { with roof }\end{array}$ & $3(1)$ \\
\hline & Thermo pine & $n$ & $y$ & $\begin{array}{l}\text { Outdoor, } \\
45^{\circ} / 90^{\circ} / 90^{\circ} \text { with roof }\end{array}$ & $3(1)$ \\
\hline & Thermo pine & $n$ & $n$ & $\begin{array}{l}\text { Outdoor, } \\
45^{\circ} / 90^{\circ} / 90^{\circ} \text { with roof }\end{array}$ & $3(1)$ \\
\hline & Thermo ash & $n$ & $y$ & $\begin{array}{l}\text { Outdoor, } \\
45^{\circ} / 90^{\circ} / 90^{\circ} \text { with roof }\end{array}$ & $3(1)$ \\
\hline & Thermo pine & $n$ & $n$ & $\begin{array}{l}\text { Outdoor, } \\
45^{\circ} / 90^{\circ} / 90^{\circ} \text { with roof }\end{array}$ & $3(1)$ \\
\hline & Acetylated pine & $n$ & $y$ & $\begin{array}{l}\text { Outdoor, } \\
45^{\circ} / 90^{\circ} / 90^{\circ} \text { with roof }\end{array}$ & $3(1)$ \\
\hline & Acetylated pine & $n$ & $n$ & $\begin{array}{l}\text { Outdoor, } \\
45^{\circ} / 90^{\circ} / 90^{\circ} \text { with roof }\end{array}$ & $3(1)$ \\
\hline
\end{tabular}

$\mathrm{Cu}-\mathrm{HDO}=$ Scots pine impregnated with Bis-(N-cyclohexyldiazeniumdioxy)-copper; $\mathrm{WRC}=$ western red cedar.

Sample set 2 included 6 specimens of Norway spruce $\left(100 \times 78 \times 15 \mathrm{~mm}^{3} /(\mathrm{L} \times \mathrm{r} \times \mathrm{t})\right)$, which were cut from one board in lengthwise direction. The specimens had a year ring orientation of an angle of $60-70^{\circ}$. After conditioning them at $20{ }^{\circ} \mathrm{C} / 65 \% \mathrm{RH}$ to an equilibrium moisture content (EMC) of approximately $12 \%$, an aqueous solution of iron (II) sulfate (4\% wt/wt) was applied by brush on the front side of all 6 specimens. The average application rate and standard deviation was $137(38) \mathrm{g} / \mathrm{m}^{2}$.

Sample set 3 included a total of 216 specimens that were made of 9 different substrates $(n=24)$ : Norway spruce, Siberian larch (Larix sibirica Ledeb.), European white oak (Quercus spp.), western red cedar (Thuja plicata Donn ex. D.Don), Scots pine heartwood (Pinus sylvestris L.), of NTR class AB [33], thermally modified Scots pine, thermally modified ash (Fraxinus excelsior L.), and acetylated radiata pine (Pinus radiata D.Don). All specimens were manufactured from commercial products. The trade name European white oak includes several European oak species, mostly Q. robur (L.) or petraea ((Matt.) 
Liebl.); an exact identification was not carried out. The thermally modified products are traded under the name Termofuru (pine) and Termoask (ash) by the Norwegian company Moelven Wood Prosjekt AS. To our knowledge, the products are manufactured in a thermal modification process at atmospheric pressure. The 24 specimens of each substrate were divided into 3 groups of 8 specimens that were exposed outdoors at $45^{\circ}, 90^{\circ}$, or $90^{\circ}$ with a "roof overhang". The specimens mounted at $45^{\circ}$ had a dimension of $375 \times 78 \times 15 \mathrm{~mm}^{3}(\mathrm{~L} \times \mathrm{r} \times \mathrm{t})$ and those mounted at $90^{\circ}$ of $150 \times 78 \times 15 \mathrm{~mm}^{3}(\mathrm{~L} \times \mathrm{r} \times \mathrm{t})$. Each substrate was represented by 4 boards (Figure 1). The year ring orientation of the 4 boards was not specified. After conditioning the substrates to EMC at $20{ }^{\circ} \mathrm{C} / 65 \% \mathrm{RH}$, the front sides of 12 of the 24 specimens per substrate were brushed with an aqueous iron (II) solution (4\% $w t / w t)$. The average application rate and standard deviation was $123(36) \mathrm{g} / \mathrm{m}^{2}$.

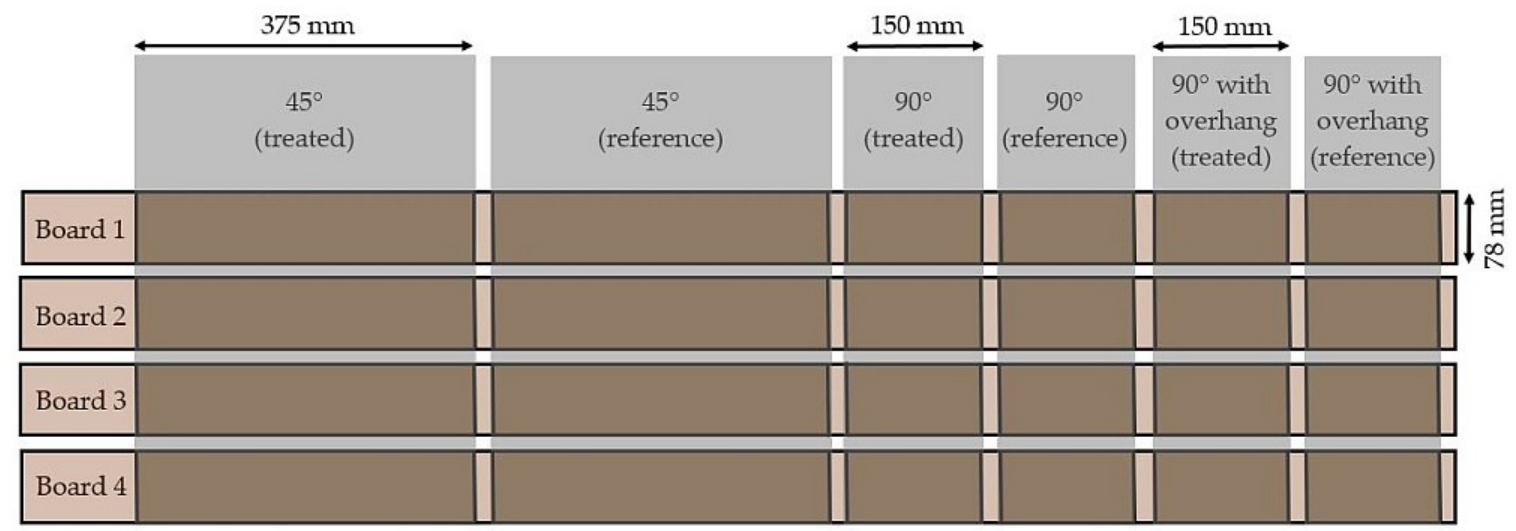

Figure 1. Preparation of the iron (II) sulfate-treated specimens and untreated specimens (reference) of sample set 3 from 4 boards for the exposure at $45^{\circ}, 90^{\circ}$, and $90^{\circ}$ with roof overhang.

\subsection{Exposure and Evaluation of Color Differences}

The three sample sets were exposed at the NTI (Norwegian Institute of Wood Technology) in Oslo, Norway (59.944580, 10.713143). The exposure was undisturbed, i.e., shading by surrounding objects was not given. CIELAB color was measured using the program ImageJ (version 1.51w) on images taken with a color-calibrated scanner (ScanMaker 9800XL plus, Mikrotek, Hsinchu, Taiwan). CIELAB is a color space defined by the International Commission on Illumination, CIE (Commission Internationale de 1'Eclairage), which expresses color as $L^{*}$ for the lightness from black (0) to white (100), $a^{*}$ from green $(-)$ to red $(+)$, and $b^{*}$ from blue $(-)$ to yellow $(+)$. Color differences were expressed as delta $E(\mathrm{dE})$.

Sample set 1 was vertically exposed to sunlight behind window glass (g-value = approx. 0.85, $\tau$ e $=$ approx. 0.75 ) in a south-easterly direction at room climate in an office on the $7^{\text {th }}$ floor from September 2017 to September 2018. During this period, the indoor air temperature varied between 20 and $24{ }^{\circ} \mathrm{C}$ and the relative humidity between $15 \%$ (winter) and $65 \%$ (late summer). The specimens were not fixed in a holder to circumvent cracking but held upright in a vertical position by a support on their back. The color of the 4 specimens was measured before extraction, after extraction and drying, after the treatment with iron (II) sulfate and drying, and after 4 and 51 weeks of exposure. The dE-values of sample set 1 refer to the color before extraction.

Three of the specimens of sample set 2 were vertically exposed to sunlight behind window glass under the same conditions as sample set 1 . Next to the 3 light-exposed specimens, the other 3 specimens from sample set 2 were stored in a ventilated box protecting them from light. Ventilated denotes passive ventilation, i.e., that the box was perforated to facilitate a free exchange between inner and outer air. CIELAB values were measured before exposure and after 42 (September 2017) and 91 weeks (September 2018). Color differences of sample set 2 refer to the color after iron (II) sulfate treatment and drying.

Sample set 3 was exposed outdoors to the south on NTI's flat roof between October 2016 and August 2018. Three specimens per substrate were mounted on racks at $45^{\circ}, 90^{\circ}$, and $90^{\circ}$ with a "roof 
overhang", respectively. The "roof overhang" was a small plate mounted horizontally at the top of the specimens, sticking out by $120 \mathrm{~mm}$ from the wall. One treated and 1 untreated specimen per substrate and exposure condition were kept as references stored at $20{ }^{\circ} \mathrm{C} / 65 \% \mathrm{RH}$ protected from light. The specimens exposed at $45^{\circ}$ were mounted with their long edge horizontal on the rack according to EN 927-3 [34]. In contrast, those specimens exposed at $90^{\circ}$ were mounted with their long edge vertical on the rack to provide enough area to study possible color differences between exposed parts and those sheltered by the overhang. CIELAB color was measured before exposure and after 5, 9, 44 , and 98 weeks. Color differences of sample set 3 refer to the color after iron (II) sulfate treatment and drying.

\section{Results}

\subsection{Indoor Exposure}

The spruce specimens with iron (II) sulfate of set 1 were slightly darker right after the treatment than the untreated references (Figures 2 and 3, Table 2). Once exposed to sunlight, the treated veneers developed a gray-bluish color during the first 4 weeks that became gradually darker over time; in comparison, the references without iron (II) sulfate showed only a slight color change (dE) of 9.93 (reference) and 8.77 (reference (extracted)). A clear influence of the extraction on the color development is not apparent, indicating that wood extractives in spruce do not contribute to the staining reaction. In the following, the term "wood extractives" denotes those extractives that are initially present in spruce, while the term "photo-induced wood extractives" denotes those that are formed during exposure, like phenoxyl radicals or quinones.

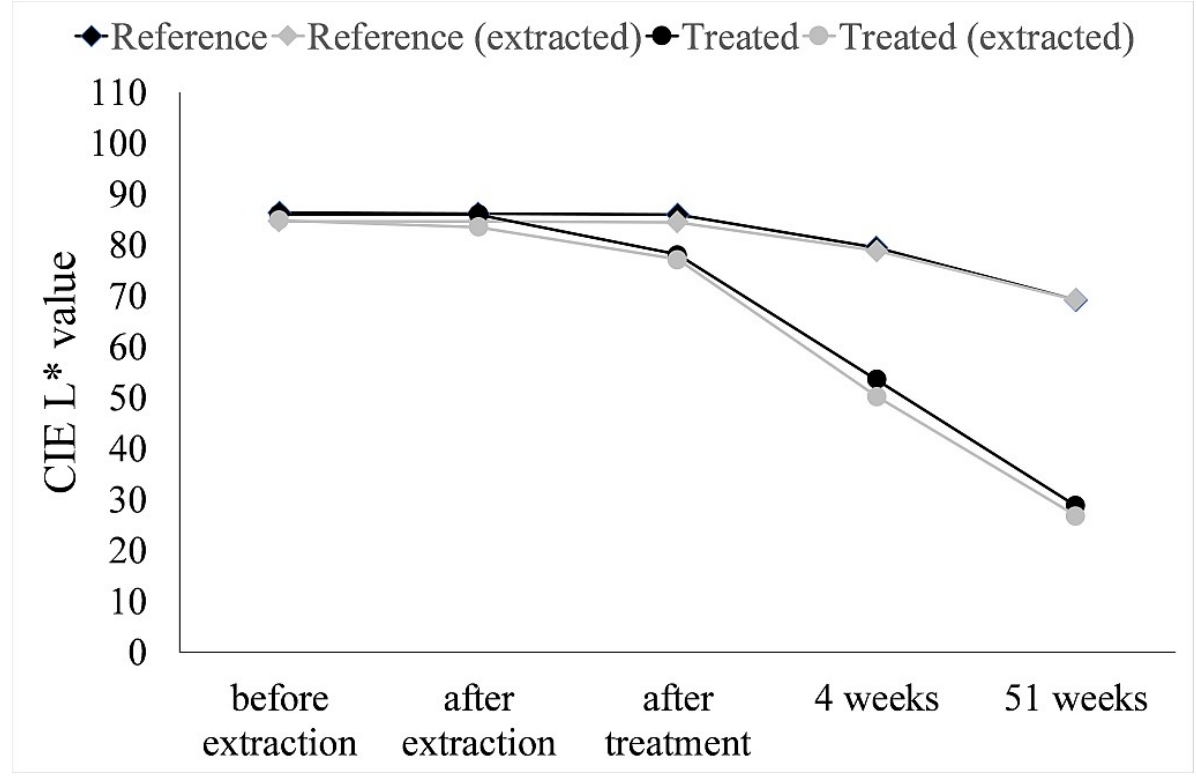

Figure 2. L-values of the extracted and non-extracted spruce specimens of sample set 1 . Treated $=$ sulfate-treated iron (II), $\mathrm{R}=$ untreated reference.

Next to the specimens that were exposed to sunlight, specimens treated with iron (II) sulfate were kept in a ventilated box protected from sunlight (sample set 2); these specimens showed only minor color differences as compared to the exposed specimens (Figures 4 and 5, Table 3). 

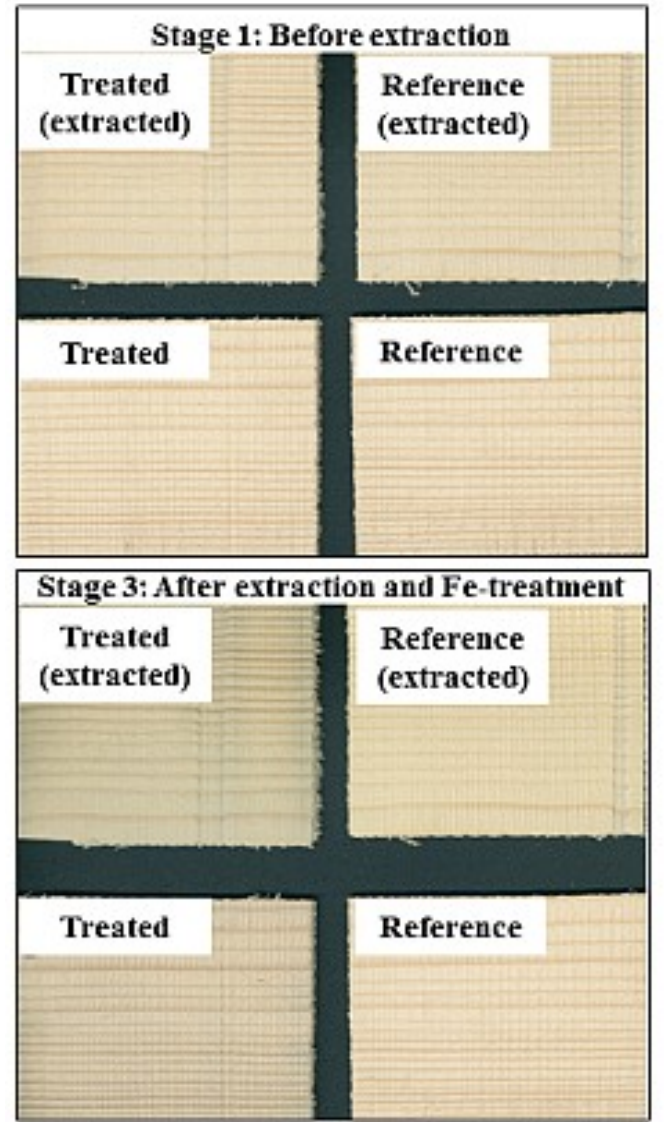
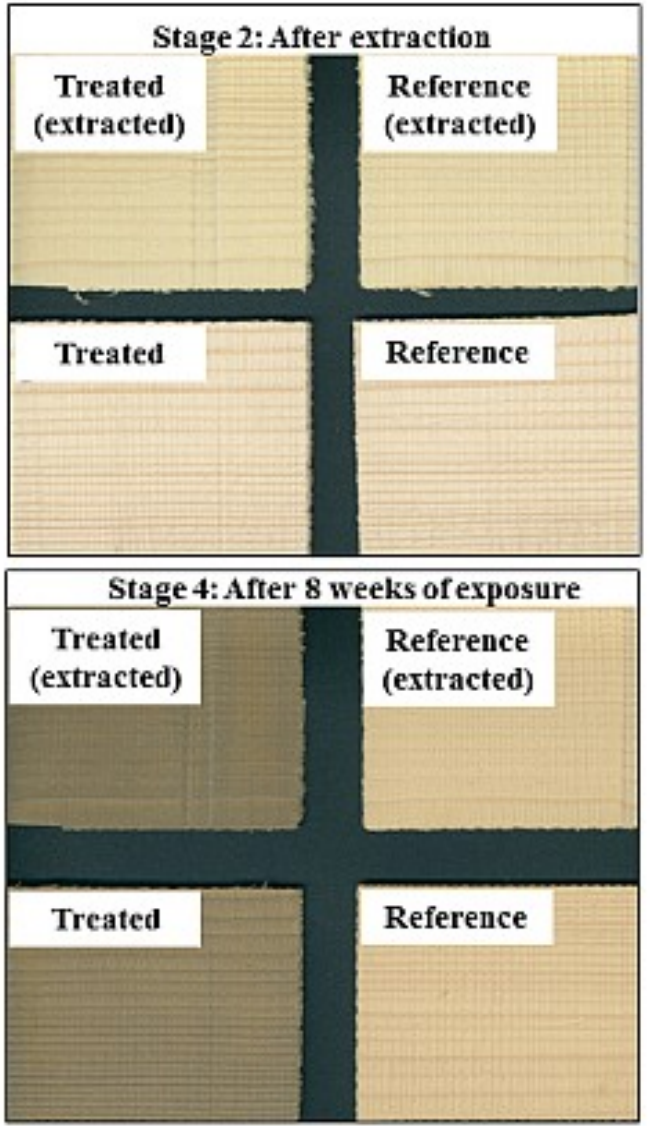

Figure 3. Scans of the extracted and non-extracted spruce specimens of sample set 1 at four experimental stages. Treated $=$ sulfate-treated iron (II), $R=$ untreated reference.

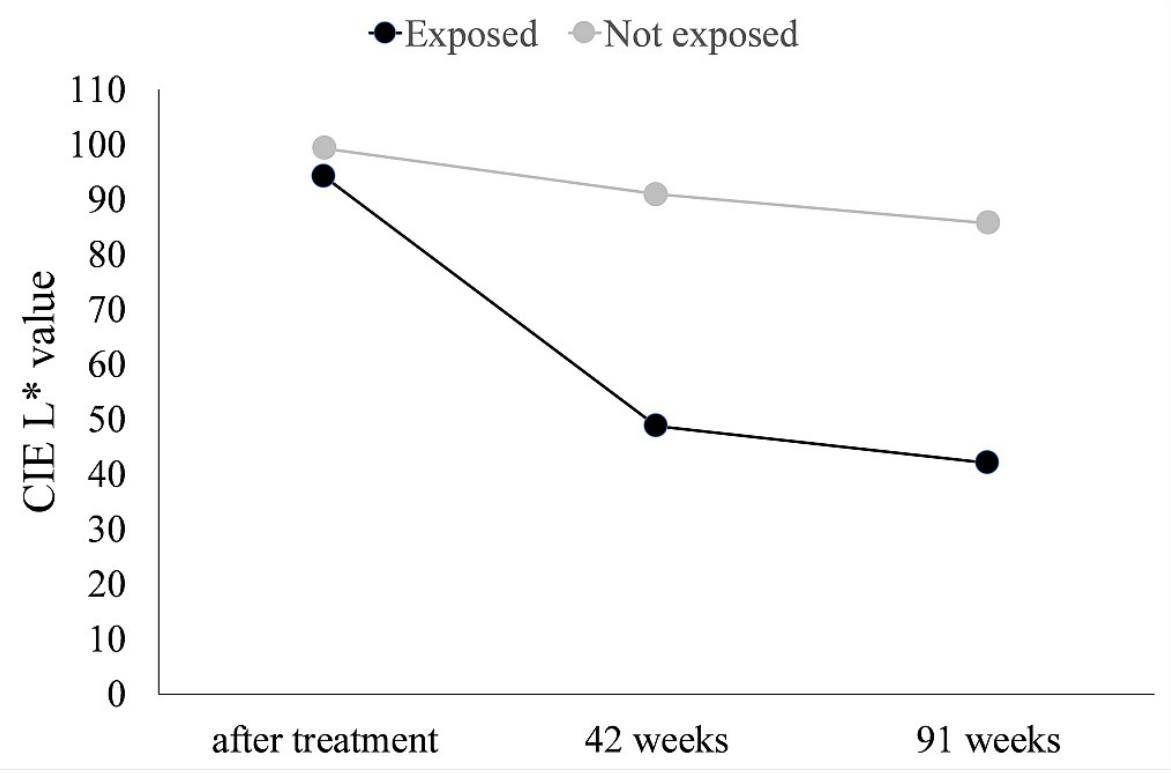

Figure 4. Mean L-values of spruce specimens of sample set $2(n=3)$ treated with iron (II) sulfate before and after 42 and 91 weeks of exposure to sun light. Three of the specimens were exposed to sunlight, 3 of them were kept in darkness (Figure 5, Table 3). 


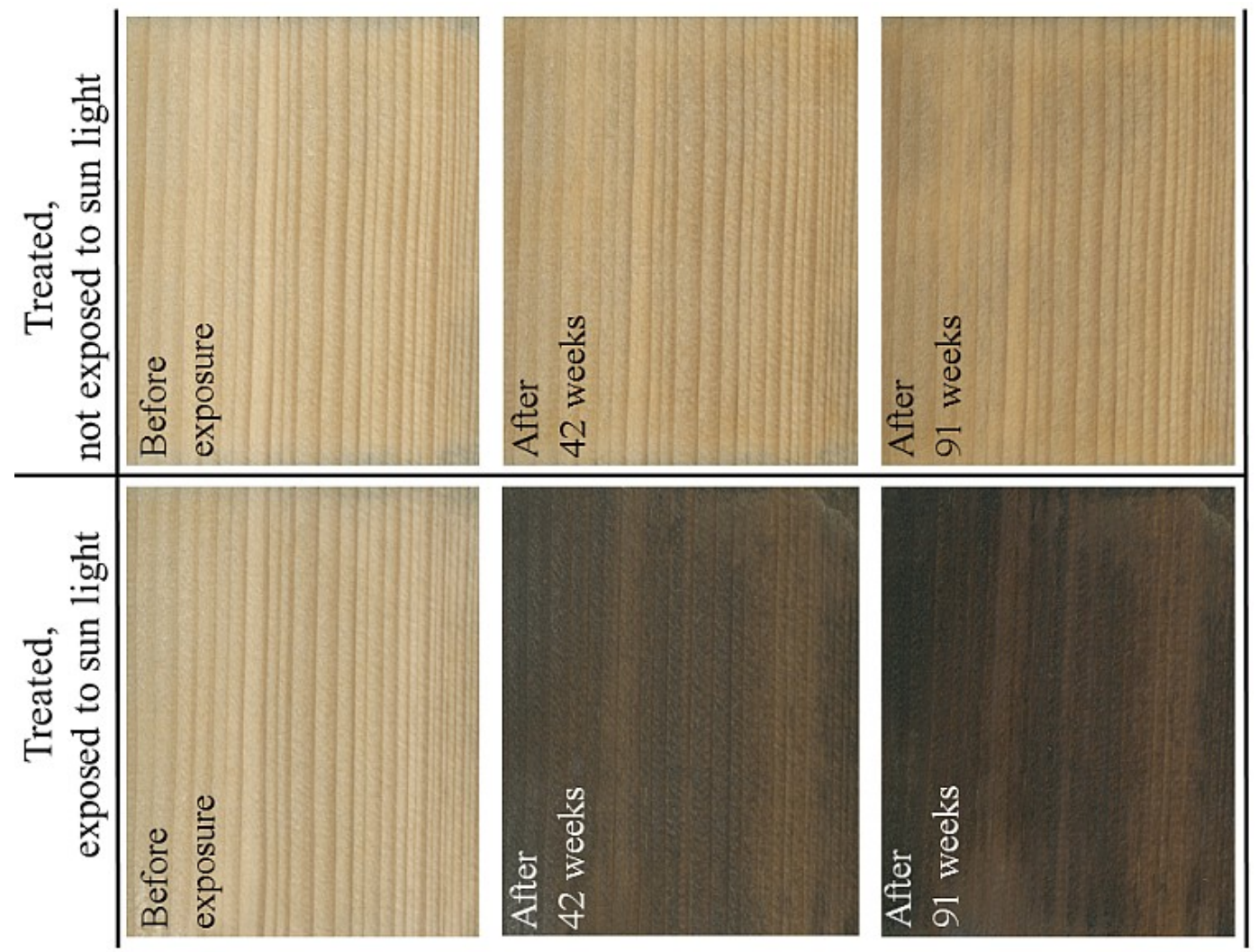

Figure 5. Scans of the specimens of set 2 treated with iron (II) sulfate before and after 42 and 91 weeks of exposure. Upper row $=$ not exposed to sunlight, lower row $=$ exposed to sun light.

Table 2. Color difference ( $\mathrm{dE}$ ) of the extracted and non-extracted spruce specimens of sample set 1 at different experimental stages referring to the color before extraction. Treated = sulfate-treated iron (II), $\mathrm{R}=$ untreated reference.

\begin{tabular}{ccccc}
\hline Treatment & $\begin{array}{c}\mathrm{dE} \\
\text { (After Extraction) }\end{array}$ & $\begin{array}{c}\mathrm{dE} \\
\text { (After Treatment) }\end{array}$ & $\begin{array}{c}\mathrm{dE} \\
\text { (After 4 Weeks) }\end{array}$ & $\begin{array}{c}\mathrm{dE} \\
\text { (After 51 Weeks) }\end{array}$ \\
\hline Reference & 0.09 & 0.23 & 9.93 & 22.05 \\
Reference (extracted) & 4.85 & 2.56 & 8.77 & 21.18 \\
Treated & 0.07 & 8.03 & 32.68 & 58.50 \\
Treated (extracted) & 5.58 & 8.01 & 34.68 & 59.56 \\
\hline
\end{tabular}

Table 3. Mean color difference (dE) of specimens of sample set $2(n=3)$ treated with iron (II) sulfate before and after 42 and 91 weeks. Three of the specimens were exposed to sunlight, 3 of them were kept in darkness (Figure 5).

\begin{tabular}{ccc}
\hline Exposed to Light & $\begin{array}{c}\mathrm{dE} \\
\text { (After 42 Weeks) }\end{array}$ & $\begin{array}{c}\mathrm{dE} \\
\text { (After 91 Weeks) }\end{array}$ \\
\hline Yes & 46.56 & 53.51 \\
No & 9.13 & 14.48 \\
\hline
\end{tabular}

\subsection{Outdoor Exposure}

The surface of specimens (sample set 3) made of pine and spruce showed slight darkening after treatment with iron (II) sulfate and drying (Figures 6 and 7). This was primarily observed around knots (Figure 7). During the first 5 weeks of exposure at $45^{\circ}$, specimens of larch, pine, spruce, and western red cedar (WRC) treated with iron (II) sulfate developed a dark gray-bluish color (Figures 6 and 8 ). This color was stable during the first year of exposure and turned into a dark gray during the second 
year. In comparison, the untreated references of larch, pine, spruce, and WRC exhibited only small color changes during the first 9 weeks of exposure but developed a similar gray color to the treated specimens after 44 weeks due to natural photodegradation and colonization by discoloring fungi. In summary, the treatment with iron (II) sulfate of larch, pine, spruce, and WRC produced a gray color that quite accurately mimicked the natural gray caused by weathering (Figures 6 and 8). This staining effect in terms of artificial graying is characterized by an immediate decrease in lightness after exposure (Figure 9). In comparison, the effect of iron (II) sulfate was less pronounced on Cu-HDO-impregnated pine and thermally modified pine and not apparent on thermally modified ash and acetylated radiata pine (Figures 6, 8 and 9). Oak darkened only slightly after exposure as it was the only substrate that had shown an immediate pronounced color change when iron (II) sulfate was applied.

Despite being exposed to less severe weathering conditions, the color of the specimens exposed at $90^{\circ}$ without a roof overhang developed similarly to that of the specimens exposed at $45^{\circ}$ (Figure 10 ). Already during the first month outside, the staining effect set in on all substrates except for acetylated radiata pine and thermally modified ash. The partial protection by an overhang delayed staining in the upper area of the specimen surface (Figure 7).

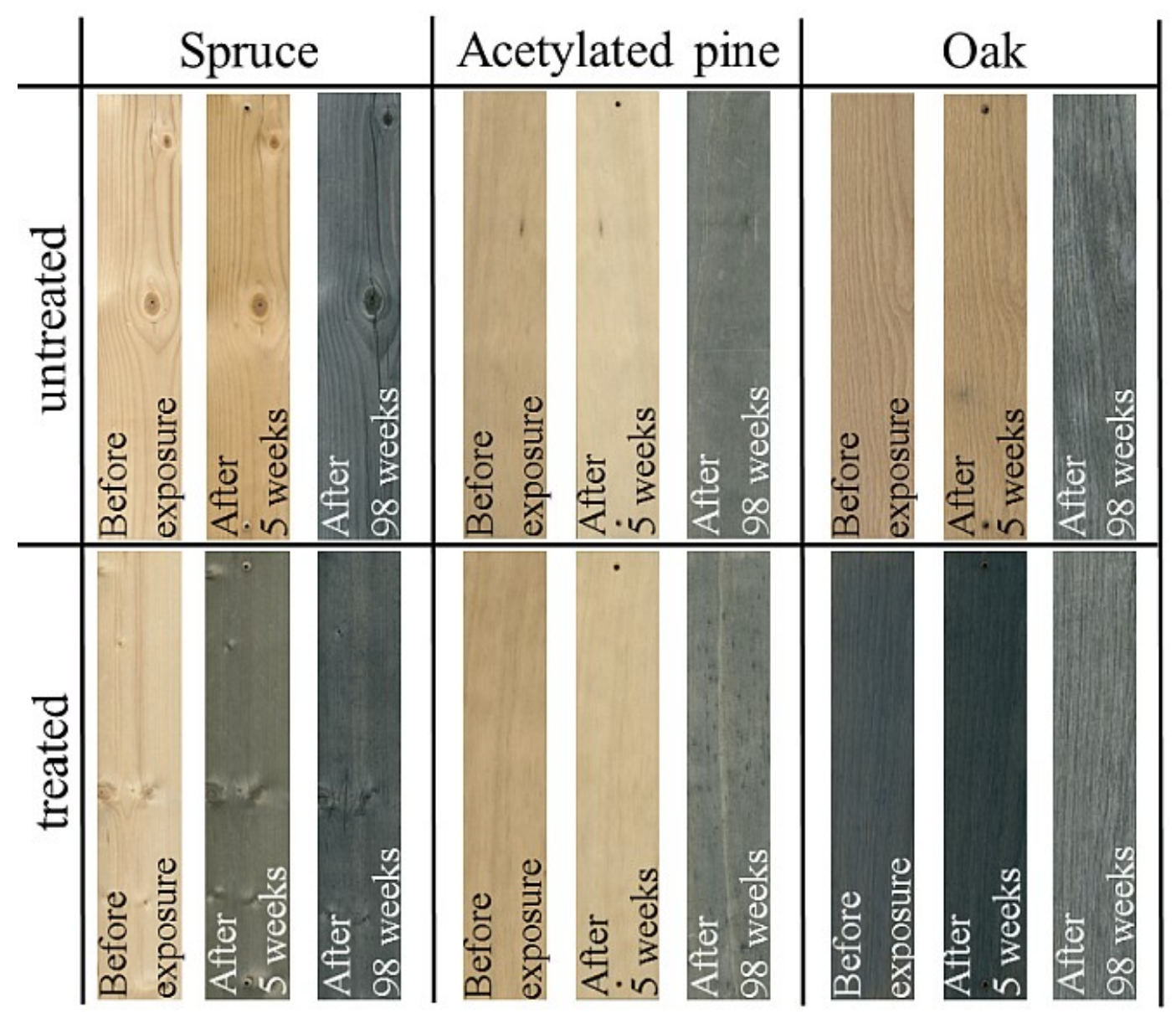

Figure 6. Untreated and iron (II) sulfate-treated specimens of spruce, acetylated radiata pine, and oak of sample set 3 before and after 5 and 98 weeks of exposure at $45^{\circ}$ to the south. 


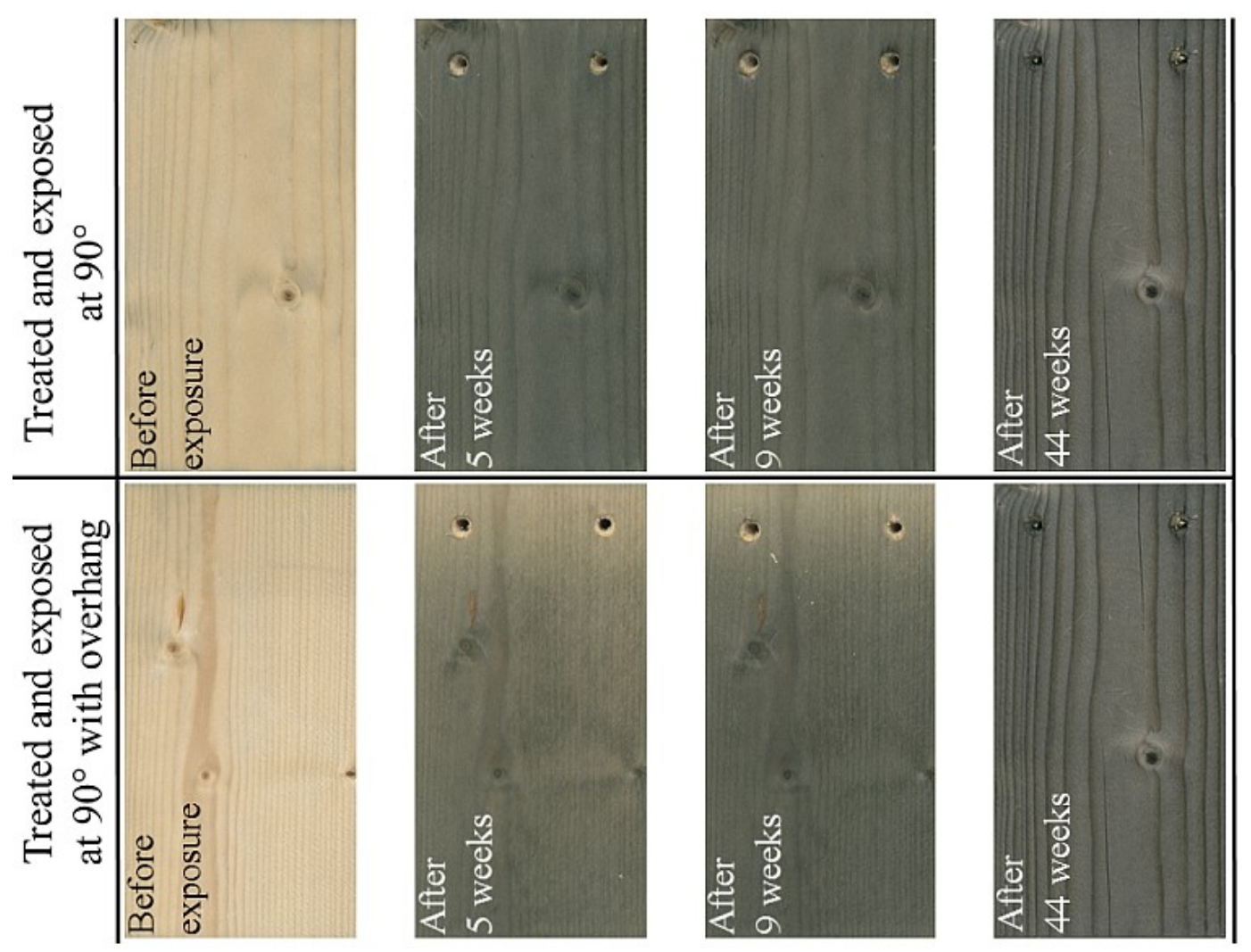

Figure 7. Spruce specimens treated with iron (II) sulfate of sample set 3 exposed at $90^{\circ}$ with and without protection by an overhang before and after 5,9 , and 44 weeks of exposure to the south.

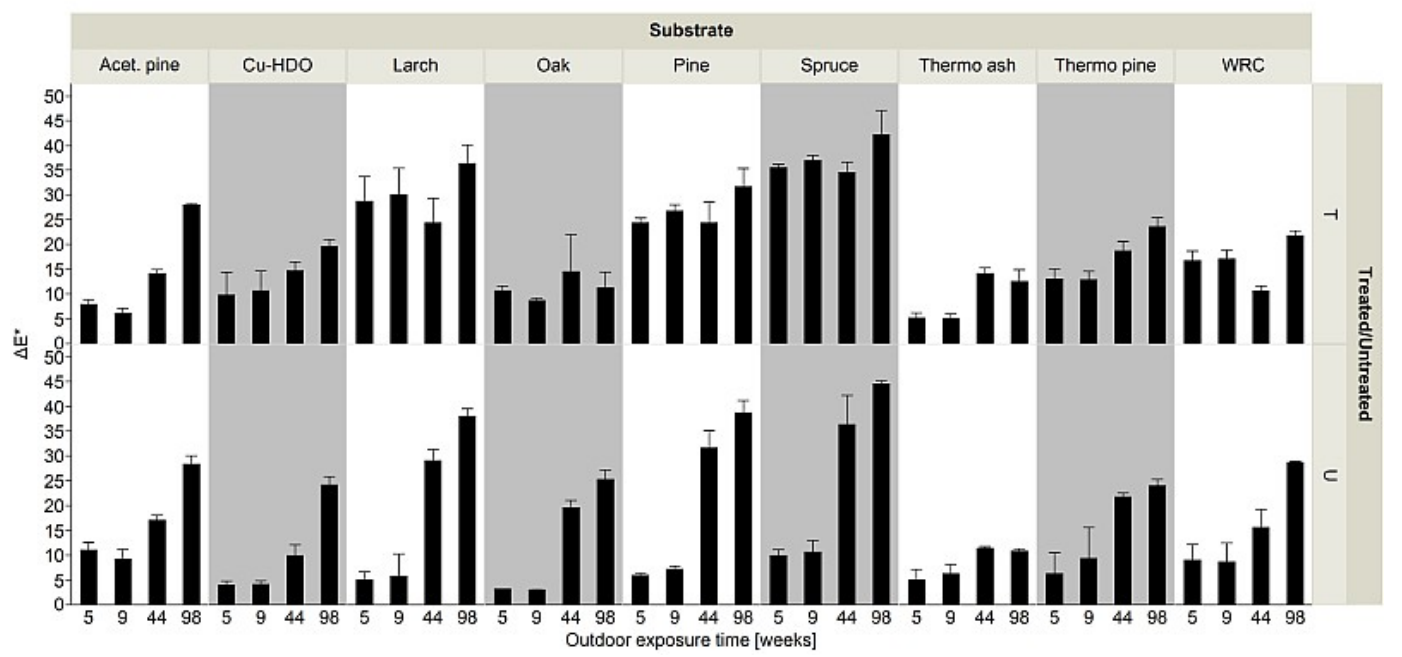

Figure 8. dE-values of the substrates treated with iron (II) sulfate (upper row) and the untreated references (lower row) of sample set 3 after 5, 9, 44, and 98 weeks of outdoor exposure at $45^{\circ}$ to the south. $\mathrm{Cu}-\mathrm{HDO}=\mathrm{Scots}$ pine impregnated with Bis-(N-cyclohexyldiazeniumdioxy)-copper; $\mathrm{WRC}=$ western red cedar. 


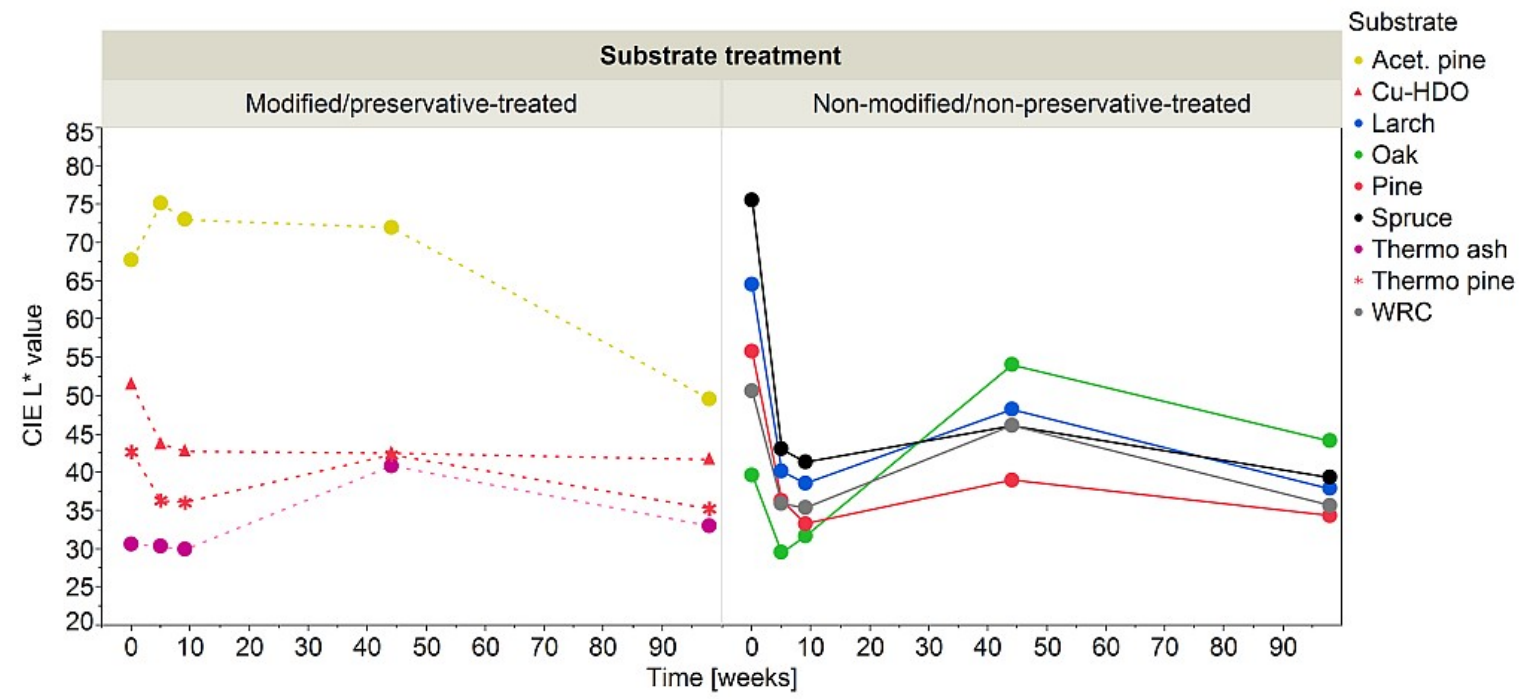

Figure 9. Mean L-values of the different substrates of sample set 3 treated with iron (II) sulfate before exposure and after $5,9,44$, and 98 weeks of exposure at $45^{\circ}$ to the south. Iron (II) sulfate's staining effect in terms of artificial graying is characterized by an immediate decrease in lightness after exposure.

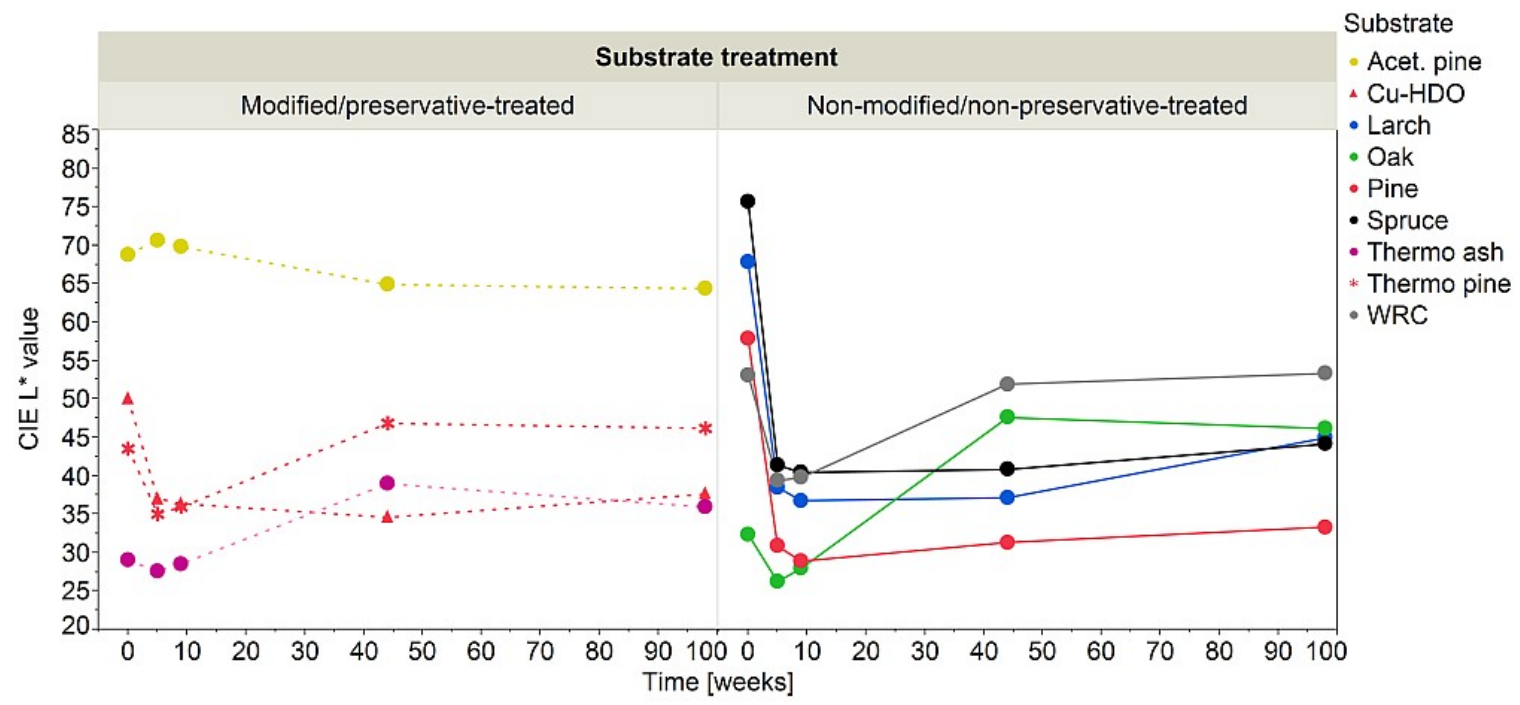

Figure 10. Mean L-values of the different substrates of sample set 3 treated with iron (II) sulfate before exposure and after $5,9,44$, and 98 weeks of exposure at $90^{\circ}$ to the south without an overhang above the specimens.

\section{Discussion}

The dark color development of the extracted spruce specimens supports our hypothesis that a complexation or any other reaction with wood extractives is not necessary for iron (II) sulfate's staining effect (Figures 2 and 3, Table 2). The slow but pronounced darkening suggests that photo-induced phenoxyl and ketyl radicals from photolysis of lignin's ether bonds turns iron (II) sulfate to iron oxide, which in turn gives wood a gray-bluish color. This is supported by the finding that iron (II) sulfate-treated spruce only showed minor darkening when protected from light either in the ventilated box (Figures 4 and 5, Table 3) or outdoors by a roof overhang (Figure 10).

A staining effect of iron (II) sulfate in terms of artificial graying on acetylated radiata pine was not seen. One reason might be that the iron ions are hindered from penetrating the cell wall matrix of acetylated wood due to a reduced pore size by cell wall bulking. This theory is supported by studies 
that found a resistance to Fenton's reagent of acetylated wood [35] and phenol-formaldehyde-modified wood [36]. Compared to the mere deposition in the lumen, iron uptake into the cell wall seems to promote its oxidation rate, reduce its loss by washing out, and increase its visibility as a colorant. Another reason might be that all free phenolic groups of lignin are acetylated, which would prevent complexation and probably the oxidation of iron (II) by phenoxy radicals. Regarding the thermally modified materials in the study, the poor staining effect of iron (II) sulfate on thermally modified pine and especially ash (Figures 6,8 and 9) has two possible explanations: one is that the inherent dark material color simply masks iron oxide's color; the other is that iron was not only found to be hindered from entering the cell wall of acetylated and phenol-formaldehyde-modified wood but also of thermally modified wood [37]. In this case, a decreased uptake of iron ions cannot be explained by cell wall bulking but possibly by a reduced swelling due to degraded hemicelluloses and cross-linking in the cell wall matrix e.g.,: [38,39].

Iron (II) sulfate has been used as a dye for wooden artefacts, furniture, or musical instruments for centuries to obtain imitations of dark, expensive wood species such as ebony (Diospyros spp.) [19]. The common main components of such dyes are metal complexes, obtained by a reaction of phenolic extractives from plants or trees and metal ions like iron [30,40]. Such a complex formation took place when the aqueous solution of iron (II) sulfate was applied to the oak specimens in the present study: Oak's color turned immediately dark blue-black after the treatment with iron (II) sulfate (Figures 6-9) because the iron (II) ion reacted with gallic acid to ferrous gallate, which subsequently oxidized to a dark ferric pyrogallate complex [27].

A complexation may also explain the darkening observed on pine and spruce after the treatment with iron (II) sulfate, which was pronounced around knots (Figures 7 and 10). A study on phenolic and lipophilic extractives in Scots pine reported on 1-7\% (w/w) stilbenes and 0.4-3\% (w/w) lignans in knots [41]. A minor content of stilbenes was found in pine stemwood, whereas lignans were not detected. In young pine trees without stem heartwood, the stilbene content was measured to be even 200 times higher than in the stem of pine. Norway spruce, particularly the knots, contains large amounts of lignans but less stilbenes than pine [42].

Different explanations can be discerned for iron (II) sulfate's limited staining of Cu-HDO impregnated pine: the substrate's original greenish color masks the staining, or HDO may have a reducing potential hindering the formation of iron (III). A mechanical hindrance as suggested by us for the acetylated radiata pine seems unlikely due to the low retentions of $\mathrm{Cu}$-HDO.

\section{Conclusions}

The treatment of wood with iron (II) sulfate results in complexation between iron and phenolic wood extractives if present. Staining proceeds also without the presence of wood extractives possibly due to the oxidization of iron (II) that is promoted by photo-induced phenoxyl and ketyl radicals from photolysis of lignin's ether bonds. The practical implication of our study is that the findings explain color differences of iron (II) sulfate-treated façades that are partly protected by, for instance, a roof overhang. This is due to the protection from solar radiation and not from precipitation as is known for natural graying. Furthermore, it was shown that iron (II) sulfate does not provide artificial graying on acetylated, thermally modified or CU-HDO-treated wood. More detailed studies using, e.g., X-ray photoelectron spectroscopy (XPS) are suggested to give a deeper insight into the mode of action of iron (II) sulfate on modified wood.

Author Contributions: Conceptualization, U.H.; methodology, U.H.; investigation, U.H., M.S., F G. and R.S.; formal analysis, U.H., M.S., F.G., R.S. and C.M.; data curation, U.H.; visualization, U.H.; writing-original draft preparation, U.H. and C.M.; writing-review and editing, U.H. and C.M.; supervision, U.H. All authors have read and agreed to the published version of the manuscript.

Funding: This research received no external funding.

Conflicts of Interest: The authors declare no conflicts of interest. 


\section{References}

1. Lin, S.Y.; Kringstad, K.P. Mechanisms in the yellowing of high-yield pulps by light: Structure and reactivity of free-radical intermediates in the photodegradation of lignin. Tappi J. 1970, 53, 2296-2300.

2. Li, C.; Ragauskas, A.J. Brightness reversion of mechanical pulps. Part XVII: Diffuse reflectance study on brightness stabilization by additives under various atmospheres. Cellulose 2000, 7, 369-385. [CrossRef]

3. Norrström, H. Light absorbing properties of pulp and pulp components. Sven. Papp. 1969, 72, $25-31$.

4. Carter, H.A. The chemistry of paper preservation: Part 2. The yellowing of paper and conservation bleaching. J. Chem. Educ. 1996, 73, 1068-1073. [CrossRef]

5. Hon, D.N.-S.; Shiraishi, N. Wood and Cellulosic Chemistry, 2nd ed.; Hon, D.N.-S., Ed.; CRC Press: Boca Raton, FL, USA, 2000; p. 928.

6. Kataoka, Y.; Kiguchi, M.; Williams, R.S.; Evans, P.D. Violet light causes photodegradation of wood beyond the zone affected by ultraviolet radiation. Holzforschung 2007, 61, 23-27. [CrossRef]

7. Feist, W.; Hon, D. Chemistry of weathering and protection. In The Chemistry of Solid Wood, 1st ed.; Rowell, R.M., Ed.; American Chemical Soc.: Washington, DC, USA, 1984; pp. 401-451.

8. Schoeman, M.; Dickinson, D. Growth of Aureobasidium pullulans on lignin breakdown products at weathered wood surfaces. Mycologist 1997, 11, 168-172. [CrossRef]

9. Evans, P.D.; Haase, J.G.; Seman, A.S.; Kiguchi, M. The search for durable exterior clear coatings for wood. Coatings 2015, 5, 830-864. [CrossRef]

10. Nejad, M.; Cooper, P. Exterior wood coatings. In Wood in Civil Engineering, 1st ed.; Concu, G., Ed.; InTech: Rijeka, Croatia, 2017; pp. 111-129.

11. Petric, M. Surface modification of wood: A critical review. Rev. Adhes. Adhes. 2013, 1, 216-247. [CrossRef]

12. Hirche, M. Wood Weathering as Design Option. Ph.D. Thesis, Norwegian University of Science and Technology, Trondheim, Norway, 2014.

13. Gobakken, L.R.; Alfredsen, G.; Høibø, O.; Vestøl, G. Aesthetical aspects of discolouring fungi on wood in-service. In Proceedings of the 1st COST FP1303 International Conference-Performance and Maintenance of Bio-Based Building Materials Influencing the Life Cycle and LCA, Kranjska Gora, Slovenia, 23-24 October 2014; pp. 17-18.

14. Podgorski, L.; Georges, V.; Izaskun Garmendia, I.; Sarachu, B.S. A fast and economic method to produce grey wooden surfaces for decking and cladding: Preliminary results. In Proceedings of the IRG/WP 40th IRG Annual Meeting, Beijing, China, 24-28 May 2009.

15. Evans, P.D.; Thay, P.; Schmalzl, K. Degradation of wood surfaces during natural weathering. Effects on lignin and cellulose and on the adhesion of acrylic latex primers. Wood Sci. Technol. 1996, 30, 411-422. [CrossRef]

16. Schnabel, T.; Petutschnigg, A. Modelling colour changes of wood for architectural CAD simulations. Comput. Aided Des. 2011, 43, 1849-1853. [CrossRef]

17. Zimmer, K.; Gobakken, L.R.; Flindall, O.; Nygaard, M. Colour changes in unpainted wooden façades-Fifty Shades of Grey. In Proceedings of the IRG/WP 49th IRG Annual Meeting, Johannesburg, South Africa, 29 April-3 May 2018.

18. Evans, P.D. Weathering of wood and wood composites. In Handbook of Wood Chemistry and Wood Composites, 2nd ed.; Rowel, R.M., Ed.; CRC Press: Boca Raton, FL, USA, 2012; pp. 166-231.

19. Høibø, O.; Nyrud, A.Q. Consumer perception of wood surfaces: The relationship between stated preferences and visual homogeneity. J. Wood Sci. 2010, 56, 276-283. [CrossRef]

20. Nyrud, A.Q.; Roos, A.; Rødbotten, M. Product attributes affecting consumer preference for residential deck materials. Can. J. For. Res. 2008, 38, 1385-1396. [CrossRef]

21. Gellerich, A.; Brischke, C.; Emmerich, L.; Meyer-Veltrup, L.; Kaudewitz, P. Evaluation of surface cracks on wood-physical assessment versus subjective sensation. In Proceedings of the IRG/WP 48th IRG Annual Meeting, Ghent, Belgium, 4-8 June 2017.

22. Cassens, D.L.; Feist, W.C. Exterior Wood in the South: Selection, Application and Finishes; GTR-69; USDA Forest Service, Forest Products Laboratory: Madison, WA, USA, 1991; p. 60.

23. Hundhausen, U. Holzfassaden in Norwegen-Tradition und moderne Architektur. In Proceedings of the Wiener Holzschutztage, Vienna, Austria, 28-29 November 2013; p. 12.

24. Evensen, F. Reading in the Park: A New Context for the Library of Kungsholmen. Independent Thesis Advanced Level (Professional Degree), KTH Royal Institute of Technology, Stockholm, Sweden, 2014. 
25. Nilsson, K. Träskyddsbehandlingar: Jämförande Provningar Av Ett Urval Traditionella Och Moderna Medel; Meddelande 168; Svenska träskyddsinstitutet: Stockholm, Sweden, 1993; p. 64.

26. Larsen, K.E.; Hakonsen, F. Kledd I Tre: Tre Som Fasademateriale, 1st ed.; Larsen, K.E., Hakonsen, F., Eds.; Gaidaros forlag AS: Oslo, Norway, 2008; p. 222.

27. Krekel, C. The chemistry of historical iron gall inks. Int. J. Forensic Doc. Exam. 1999, 5, 54-58.

28. Klöckl, I. Chemie der Farbmittel. In der Malerei, 1st ed.; Klöckl, I., Ed.; Walter de Gruyter GmbH \& Co KG: Berlin, Germany, 2015; p. 691.

29. Karpenko, V.; Norris, J.A. Vitriol in the history of chemistry. Chem. Listy 2002, 96, 997-1005.

30. Canevari, C.; Delorenzi, M.; Invernizzi, C.; Licchelli, M.; Malagodi, M.; Rovetta, T.; Weththimuni, M. Chemical characterization of wood samples colored with iron inks: Insights into the ancient techniques of wood coloring. Wood Sci. Technol. 2016, 50, 1057-1070. [CrossRef]

31. Edlund, M.-L.; Nilsson, K.; Henningsson, B. Jämförande Provning Av Ett Ett Uravl Traditionella Och Moderna medel; Svenska Träskyddsinstitutet: Stockholm, Sverige, 1997; p. 9.

32. Sandermann, W.; Lüthgens, M. Untersuchungen über Verfärbungen von Hölzern. Holz als Roh-Und Werkst. 1953, 11, 435-440. [CrossRef]

33. NWPC. Nordic Wood Protection Classes and Product Requirements for Industrially Protected Wood. Part 1: Scots Pine and Other Permeable Softwoods; Nordic Wood Preservation Council: Stockholm, Sweden, 2017; p. 8.

34. CEN. EN 927-3:2012: Paints and Varnishes-Coating Materials and Coating Systems for Exterior Wood-Part 3: Natural Weathering. Test European Committee for Standardization, 2012. Available online: https:/standards.iteh.ai/catalog/standards/cen/71371f20-5bfb-4d7b-8e3c-3925e7d7c92f/en-,927-32012 (accessed on 23 April 2020).

35. Hosseinpourpia, R.; Mai, C. Mode of action of brown rot decay resistance of acetylated wood: Resistance to Fenton's reagent. Wood Sci. Technol. 2016, 50, 413-426. [CrossRef]

36. Hosseinpourpia, R.; Mai, C. Mode of action of brown rot decay resistance in phenol-formaldehyde-modified wood: Resistance to Fenton's reagent. Holzforschung 2016, 70, 253-259. [CrossRef]

37. Hosseinpourpia, R.; Mai, C. Mode of action of brown rot decay resistance of thermally modified wood: Resistance to Fenton's reagent. Holzforschung 2016, 70, 691-697. [CrossRef]

38. Wikberg, H.; Maunu, S.L. Characterisation of thermally modified hard-and softwoods by 13C CPMAS NMR. Carbohydr. Polym. 2004, 58, 461-466. [CrossRef]

39. Esteves, B.; Pereira, H. Wood modification by heat treatment: A review. BioResources 2009, 4, 370-404.

40. Kielmann, B.C.; Butter, K.; Mai, C. Modification of wood with formulations of phenolic resin and iron-tannin-complexes to improve material properties and expand colour variety. Eur. J. Wood Wood Prod. 2018, 76, 259-267. [CrossRef]

41. Willför, S.; Hemming, J.; Reunanen, M.; Holmbom, B. Phenolic and lipophilic extractives in Scots pine knots and stemwood. Holzforschung 2003, 57, 359-372. [CrossRef]

42. Willför, S.; Reunanen, M.; Eklund, P.; Sjöholm, R.; Kronberg, L.; Fardim, P.; Pietarinen, S.; Holmbom, B. Oligolignans in Norway spruce and Scots pine knots and Norway spruce stemwood. Holzforschung 2004, 58, 345-354. [CrossRef]

(C) 2020 by the authors. Licensee MDPI, Basel, Switzerland. This article is an open access article distributed under the terms and conditions of the Creative Commons Attribution (CC BY) license (http://creativecommons.org/licenses/by/4.0/). 